УДК 378.147:615.1.003.1

М. В. БІЛОУС ${ }^{1}$, канд. фарм. наук, О. П. ШМАТЕНКО ${ }^{1}$, д-р фарм. наук, проф.,

О. А. РИЖОВ ${ }^{2}$, д-р фарм. наук, проф.,

Т. С. РАЙКОВА ${ }^{2}$, канд. фарм. наук, доцент, Д. В. ДРОЗДОВ ${ }^{1}$

${ }^{1}$ Украӥнська військово-медична академія, м. Київ

2 Запорізький державний медичний університет

ЛОГІСТИЧНИЙ АУТСОРСИНГ У ФАРМАЦЇ̈: ТЕОРІЯ ТА ПРАКТИКА

Ключові слова: фармацевтична логістика, аутсорсинг

\author{
M. V. BILOUS ${ }^{1}$, O. P. SHMATENKO ${ }^{1}$, O. A. RYZHOV ${ }^{2}$, T. S. RAIKOVA ${ }^{2}$, D. V. DROZDOV ${ }^{1}$ \\ ${ }^{1}$ Ukrainian Military Medical Academy, Kyiv \\ ${ }^{2}$ Zaporizhzhia State Medical University
}

\title{
LOGISTIC OUTSOURCING IN PHARMACY. THE THEORY AND PRACTICE
}

Key words: pharmaceutical logistics, outsourcing

На сьогодні впровадження і використання логістичної концепції до управління ресурсами дає змогу фармацевтичним підприємствам підвищити їхню соціальну, екологічну та економічну ефективність $[1,2]$. Логістична концепція передбачає необхідність системного підходу до управління сукупністю каналів, через які всі матеріальні і супутні їм фінансові, кадрові й інформаційні потоки в процесі закупівлі, виробництва і розподілу лікарських засобів надходять на фармацевтичне підприємство, переміщуються у середині нього, а також вибувають із нього $[1,2]$. Логістична стратегія фармацевтичних підприємств спрямована на виконання восьми правил логістики - своєчасне забезпечення споживача потрібними лікарськими засобами, високої якості, за конкурентним рівнем цін, в необхідному обсязі, у визначений термін, у потрібному місці, з урахуванням персоніфікованості системи обслуговування, яка розробляється для кожного споживача $[1,2]$. Це потребує глибоких знань, вмінь і навичок, компетенції у кожній сфері діяльності, а також масштабного матеріального та технічного забезпечення (логістичних активів) фармацевтичного підприємства. Тому зараз більшість фармацевтичних підприємств, формуючи логістичну стратегію, використовують аутсорсинг: зосереджують свою діяльність у спеціалізованій сфері, яка відіграє роль основного (ключового) виду діяльності, тобто «ключової компетенції», другорядні, менш важливі функції вони часто передають іншим спеціалізованим підприємствам, оскільки аутсорсинг-послуги коштують дешевше, ніж підтримка всіх бізнес-процесів усередині фармацевтичного підприємства $[3,4]$.

Новітні потреби часу вимагають набуття майбутніми провізорами-спеціалістами не тільки професійних знань та вмінь, але й постійного економічного удосконалення. Адже без оволодіння основними економічними поняттями неможливо уявити професійну діяльність провізора. Тому виникає необхідність у більш поглибленому вивченні фармацевтичної логістики та іiї стратегій, а саме логістичного аутсорсингу, для удосконалення процесу викладання майбутнім провізорам-спеціалістам.

Мета роботи полягає в дослідженні сутності поняття, рівнів та видів логістичного аутсорсингу у практичній фармації.

\section{М ат е рі али т а методи дослідження}

Для досягнення мети дослідження виконано аналіз закордонної і вітчизняної наукової літератури та чинної нормативно-правової бази України. Методами дослідження є бібліографічний та аналітичний.

(C) Колектив авторів, 2017 


\section{Р езультати дослідження та обговоре нн я}

В Україні термін «аутсорсинг» стали фактично використовувати лише у 90-ті роки минулого століття $[1,2,5,6]$. Аналіз джерел літератури показав походження терміну аутсорсинг (outsourcing) від англійських слів outside resourcesusing, що означає «використання зовнішніх ресурсів», але подальші тлумачення сутності аутсорсингу є різноманітними.

У Фармацевтичній енциклопедії аутсорсинг трактується як найм підприємством якого-небудь стороннього суб'єкта господарювання для виконання одного із видів своєї діяльності, який раніше виконувався ресурсами цього підприємства, або передавання допоміжних, підтримуючих чи супутніх функцій зовнішнім виконавцям (провайдер послуг), які спеціалізуються в конкретній галузі та мають відповідні знання, досвід, технічне оснащення та ін. [7].

Тобто, під аутсорсингом можна розуміти винесення будь-яких допоміжних або навіть основних бізнес-процесів за організаційні та фізичні кордони компанії.

Мовою бізнесу аутсорсинг можна визначити як делегування певних функцій стороннім організаціям, які спеціалізуються на відповідних видах, переважно, управлінської діяльності. У сфері маркетингу фірма може довірити зовнішній стороні виконання окремих маркетингових функцій: планування маркетингової діяльності, PR-підтримку та ін. У цьому разі використовується основний принцип аутсорсингу - «залишаю собі тільки те, що можу робити краще за інших, передаю зовнішньому виконавцеві те, що він робить краще за інших» [5]. Отже, аутсорсинг може бути частиною маркетингової діяльності, тому що забезпечує ринкову орієнтацію фармацевтичної фірми незалежно від виконуваних функцій.

Концепція логістики тісно пов'язана 3 концепцією маркетингу, оскільки вони грунтуються на принципах комплексності та синхронності, мають універсальний характер, агреговані показники ефективності й застосовуються в усіх сферах життя суспільства, на всіх ієрархічних рівнях управління. Головна мета маркетингу фармацевтичного підприємства - збільшення прибутку при забезпеченні конкурентоспроможності лікарських засобів за пріоритетними критеріями маркетингу, а головна мета логістики - оптимізація витрат усіх учасників фармацевтичних логістичних ланцюгів, починаючи від створення лікарських засобів і закінчуючи його постачанням конкретному споживачу. Використання інтегрованої (маркетинго-логістичної) концепції управління забезпечить фармацевтичному підприємству мінімізацію загальних витрат і максимізацію комплексу корисності за заданого рівня обслуговування, а також прискорення потокових процесів і підвищення здатності фармацевтичної організації адаптуватися до змін динамічного зовнішнього середовища [6].

На сьогодні аутсорсинг слід розглядати як одну з основних логістичних стратегій $[7,8]$, яку використовують вітчизняні фармацевтичні підприємства [4]. По оцінках Української логістичної асоціації, в Україні тільки формується ринок логістичного аутсорсингу, але прогнозують надалі його зростання достатньо швидкими темпами, близько 30-40\% на рік [9].

Сутність логістичного аутсорсингу визначається як процес делегування окремої логістичної функції або бізнес-процесу підприємства на довгостроковій контрактній основі для оптимізації діяльності підприємства та скорочення виробничо-технологічних, інтелектуальних та економічних витрат, а також відповідних ресурсів [10].

Якщо раніше аутсорсинг у практичній фармації фактично не був закріплений на законодавчому рівні, то тепер у п. 104 Ліцензійних умов провадження господарської діяльності з виробництва лікарських засобів, оптової та роздрібної торгівлі лікарськими засобами, імпорту лікарських засобів (окрім активних фармацевтич- 
них інгредієнтів) чітко зазначено, що створена ліцензіатом система якості має гарантувати забезпечення контролю та огляд будь-якої зовнішньої (аутсорсингової) діяльності на всі види діяльності, що стосуються дистрибуції [11]. Запровадження аутсорсигу надає можливість, у разі дотримання необхідних умов, працювати іншим учасникам фармацевтичного ринку напряму з виробниками фармацевтичної продукції через невеликі оптові фірми. Це дасть змогу фармацевтичним виробникам заходити на регіональні ринки зі значним здешевленням витрат на логістичні операції [12].

Але перш ніж фармацевтичне підприємство вирішить, чи $є$ у нього необхідність у використанні аутсорсингу, потрібно встановити ключові компетенції (core competence) підприємства. Правильно вибрати той процес (або функцію), які можна передавати на аутсорсинг, дає змогу системний аналіз діяльності підприємства (IDEF (ICAM Definition) стандарти) за методологією аналізу та проектування систем SADT (Structured Analysis and Design Technique). Оскільки саме системний аналіз використовують для підвищення ступеня обгрунтованості рішень у складних (слабоструктурованих) системах.

На підставі вивчення світового досвіду впровадження логістичного аутсорсингу на підприємствах $[4,8,9,13,14]$ встановлено чотири рівні декомпозиції (процесу розділення, що дає змогу розглядати будь-яку досліджувану систему як складну, яка складається з окремих взаємопов'язаних підсистем, вони, в свою чергу, також можуть бути розділеними на частини). Ці рівні декомпозиції забезпечують отримання загального уявлення про логістичне обслуговування 3 позиції системного аналізу, які відповідають загальноприйнятій класифікації рівнів логістики $[9,13,14]$.

- Логістика першого рівня (first party logistics - 1PL) - це внутрішня логістика, де всі послуги з транспортування, складського зберігання, митних операцій і супутнього сервісу зосереджені всередині компанії замовника.

- Логістика другого рівня (second party logistics - 2PL) - це зовнішня логістика, що дає змогу виконувати традиційний спектр послуг, пов'язаних із транспортуванням та складуванням.

- Логістика третього рівня (third party logistics - 3PL) - це зовнішня логістика, що дає змогу інтегрувати усі логістичні послуги у єдиний комплекс, який включає також такі додаткові послуги, як проміжне зберігання вантажу, так званий «cross docking», проектування та розроблення інформаційних систем, використовування послуг субпідрядників та інше.

Світова теорія стверджує, що компанія 3PL-провайдер має надавати транспортно-експедиційні послуги та послуги доданої вартості, такі як навантаження та розвантаження, послуги по комплектації асортименту, складські послуги, управління вантажопотоками, маркетингові та фінансові послуги. Сучасні 3PL-провайдери пройшли шлях синергійного поєднання специфічних послуг, що раніше надавалися відокремленим операторам логістичного ринку. 3PL-сервіс являє собою багатопрофільного консультанта, який пропонує та реалізує рішення для управління ланцюжком постачань $[9,13,14]$.

- Логістика четвертого рівня (fourth party logistics - 4PL) - це зовнішня і внутрішня логістика. Компанія-провайдер, виконуючи функції 3PL-провайдера логістичних послуг, також виконує функції планування логістичних операцій, найм та координацію роботи субпідрядників других рівнів, усі пов'язані фінансові транзакції, ведення документації тощо.

Для діяльності 4PL-провайдера важливо дотримуватися нейтралітету та незалежності, щоб запобігати будь-яких конфліктів інтересів. Тому часто 4PL застосовують сервіс 2PL та 3PL, володіючи лише комп'ютерними системами та інтелектуальною 
власністю. Фактично 4PL від 3PL відрізняє також те, що робота першого 3 підприємством-замовником основана на ERP-системі (Enterprise Resource Planning - планування ресурсів підприємства). Ця система здатна звести до мінімуму ризики в логістичному ланцюжку замовника, забезпечуючи його при цьому функціями стратегічного та оперативного управління $[9,13,14]$.

- Логістика п'ятого рівня (fifth party logistics - 5PL) - це інтернет-логістика. 5PLпровайдери використовують всесвітню мережу як єдину віртуальну площу для виконання повного спектра логістичних задач. Проте, в нашій країні такий рівень сервісу ще не поширився достатньою мірою $[9,13,14]$.

Наведені вище рівні логістики показують розширення аутсорсингу як сучасної форми оптимізації логістичних бізнес-процесів, що на думку провідних вітчизняних вчених схематично можна подати так: $1 \mathrm{PL}$ (логістичний інсорсинг) $\rightarrow$ 2PL (частковий логістичний аутсорсинг) $\rightarrow$ 3PL (комплексний логістичний аутсорсинг) $\rightarrow$ 4PL (інтегрований логістичний аутсорсинг) $\rightarrow$ 5PL («віртуальна» логістика) [15].

На вітчизняному ринку не так активно, як на зарубіжних, але також проходить процес трансформації окремих логістичних структур у логістичних операторів, які займаються наданням комплексу логістичних послуг. Водночас спостерігається вихід потужних логістичних операторів світового масштабу на український ринок, що сприятиме конкуренції та розширенню кола пропозицій $[4,9]$.

На сьогодні спостерігається впровадження аутсорсингу у багатьох сферах логістичної діяльності фармацевтичних підприємств [4], але особливе значення він має у сфері складських послуг. Вітчизняні науковці, які займаються вивченням логістичного аутсорсингу в Україні, підкреслюють, що вітчизняна складська логістика вимагає серйознішої доробки. Вони пропонують головний напрям інвестицій у складській логістиці (окрім нарощування обсягів будівництва складів) - підвищення автоматизації процесів зберігання та переміщення вантажів [13].

Зарубіжні автори, які займаються вивченням складської логістики, відзначають існування як переваг, так і недоліків аутсорсингу складського комплексу. До переваг відносять: більше концентрації на основному виді діяльності; зниження витрат; менше капітальних інвестицій; більш гнучка продуктивність. На думку авторів, існує й кілька недоліків аутсорсингу у сфері складських послуг: ціни не обов'язково нижчі, ніж передбачалось; залежність від 3PL-провайдера; зниження контролю над процесом [16].

Також деякі науковці акцентують увагу на необхідності тісної співпраці між підприємництвом-замовником та 3PL-провайдером для успішного аутсорсингу складського комплексу. Вони наголошують, що велике значення має залученість підприємства до своїх складських операцій, оскільки на практиці вони відсторонюються від складської логістики та залишають 3PL-провайдера самостійно розбиратися 3 наслідками запізнілого замовлення, неякісних прогнозів, сильних коливань робочого навантаження або неефективної структури замовлень [16]. Дуже важливо, щоб менеджер фармацевтичного підприємства мав професійні компетенції з фармацевтичної логістики, міг адекватно планувати логістичні операції, уникаючи вищезазначених недоліків, й ефективно керувати процесом разом з 3PL-провайдером.

Сьогодні у фармації значний розвиток отримав аутсорсинг інформаційних технологій (IT-аутсорсинг) [4]. А в деяких джерелах літератури IT-аутсорсинг вважають навіть лідером аутсорсингових операцій у світі через високі темпи розвитку комп'ютерних технологій [17]. Напрям IT-аутсорсингу стає все більше привабливим для фармацевтичних підприємств, оскільки впровадження IT-технологій, без яких не можлива повноцінна робота підприємства, потребує певних капітальних витрат, які необхідні для закупівлі серверного та мережевого обладнання, сучасних апаратних і 
програмних рішень. Тому забезпечення зменшення необхідних витрат можливо шляхом впровадження IT-аутсорсингу [18].

За ступенем повноти процесів, переданих на виконання аутсортеру (постачальнику послуг аутсорсингу) існує декілька видів аутсорсингу IT-послуг, якими може скористатися фармацевтична компанія $[19,20]$.

- Аутсорсинг IT-інфраструктури (всі IT-процеси) - класичний вид аутсорсингу IT-послуг. Всі роботи з впровадження та підтримки окремих систем (ERP, CRM та ін.) виконує зовнішній підрядник. При цьому IT-послуги, які відносяться до інших систем, здійснюються власними силами IT-підрозділу компанії. Цей вид аутсорсингу застосовують в більшості великих і середніх компаній, що використовують типове програмне забезпечення (ПЗ) корпоративного рівня (системи ERP, CRM, системи документообігу). У разі добре розвиненого IT-відділу цей варіант може бути перехідним до другого [19, 20].

- Аутсорсинг частини IT-інфраструктури. У цьому разі на аутсорсинг передаються не всі ІТ-процеси, пов'язані з інформаційною системою, а тільки деякі з них. Наприклад, впровадження системи виробляється силами зовнішнього підрядника, а iї супровід - власними силами. Інший приклад - підтримка системи здійснюється власними силами, а іiі розвиток - силами зовнішнього підрядника. Цей варіант застосовують, якщо є добре розвинений ІТ-відділ, що виконує підтримку ПЗ власної розробки і бере на себе функції з підтримки покупних систем [19, 20].

- Аутсорсинг апаратного забезпечення. Використовується апаратне забезпечення зовнішнього підрядника і здійснюється аутсорсинг процесу підтримки цього обладнання. Цей вид аутсорсингу недостатньо розвинений в Україні. Застосовується, зокрема, в деяких компаніях, заснованих західним капіталом [19, 20].

- Аутсорсинг окремих процесів у рамках усієї IT-інфраструктури. Від попереднього виду відрізняється тим, що зовнішні підрядники виконують повний цикл окремих процесів для всієї ІТ-інфраструктури компанії. Застосовується в деяких малих і середніх компаніях, де IT-стратегія не передбачає розширення IT-відділу і фактор безпеки не є ключовим $[19,20]$.

- Повний IT-аутсорсинг (немає власних IT-фахівців у компанії). Максимально повний варіант попереднього виду аутсорсингу - власного IT-відділу в компанії немає і всі ІТ-функції виконують зовнішні підрядники. Застосовується в середніх і невеликих компаніях, де фактор безпеки не є ключовим. У більшості випадків компанія, що вирішила скористатися послугами IT-аутсорсингу, починає з форми 1, переходячи у міру розвитку і зростання довіри до інших форм $[19,20]$.

Таким чином, під час виконання дослідження сутності, рівнів та видів логістичного аутсорсингу у практичній фармації виникає переконливе розуміння того факту, що на сучасному етапі розвитку економіки значно зростає роль логістичної діяльності на вітчизняних фармацевтичних підприємствах, а напрям логістичного аутсорсингу у практичній фармації є актуальним. Тому було б доцільно впровадити тему «Логістичний аутсорсинг у практичній фармації» в навчальний процес студентів фармацевтичних факультетів (ВНЗ), провізорів-інтернів, магістрантів та слухачів факультетів післядипломної освіти. Адже в процесі навчання майбутні провізори-спеціалісти мають оволодіти основними поняттями, які розкривають практичне застосування інструментів та стратегій системи фармацевтичної логістики. Це поліпшить теоретичну і практичну підготовку майбутніх провізорів-спеціалістів та дасть можливість у подальшому застосувати їм отримані знання з логістичного аутсорсингу в діяльності фармацевтичних підприємств. Обгрунтування доцільності викладання основних аспектів логістичного аутсорсингу у фармації майбутнім провізорам-спеціалістам буде темою нашого окремого дослідження. 


\section{В и с н о в к и}

1. Аутсорсинг є однією з основних логістичних стратегій фармацевтичних підприємств, який активно використовують в сфері IT-технологій та складських послуг.

2. Для забезпечення якісного надання аутсорсингових послуг необхідна нормативно-правова база, що стандартизує взаємодію між підприємством-замовником та аутсорсером, та розроблення стандартів надання послуг з певного виду аутсорсингу.

3. Впровадження логістичного аутсорсингу як сучасної форми оптимізації логістичних бізнес-процесів потребує формування професійної компетенції у майбутніх провізорів-спеціалістів із фармацевтичної логістики, їі інструментів та стратегій, тобто підготовки конкурентоспроможних фахівців, які здатні працювати за різноманітними напрямами практичної фармації.

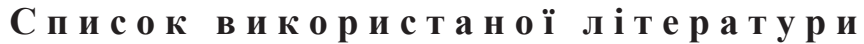

1. Сагайдак-Нікітюк Р. В., Посилкіна О. В. Сучасні вимоги до компетенції логістів в умовах фармацевтичної галузі // Запорож. мед. журн. - 2010. - № 1 (12). - С. 87-91.

2. Посилкіна О. В., Сагайдак Р. В., Громовик Б. П. Фармацевтична логістика: монографія. - Харків: Вид-во НФаУ «Золоті сторінки», 2004. - 320 с.

3. Довба М. О., Русановська О. А., Трофимчук Н. Ю. Аутсорсинг на ринку логістичних послуг: перспективи в Україні // Наук. записки Львів. ун-ту бізнесу та права. - 2011. - Вип. 7. - С. 70-74.

4. Фармацевтический аутсорсинг по-украински // Аптека-online [Електронний pecypc]. - Режим доступу: http://www.apteka.ua/article/215277

5. Райкова T. С. Новейший маркетинг в фармации и его направления - раздел преподавания «Маркетинга в фармации» провизорам-интернам // Запорож. мед. журн. - 2008.- № 4. - С. 159-163.

6. Громовик Б. П., Унгурян Л. М. Фармацевтична логістика: фокус на допомозі пацієнту: монографія // Львів. нац. мед. ун-т ім. Данила Галицького. - Львів: Растр-7, 2013. - $210 \mathrm{c}$.

7. Фармацевтична енциклопедія / Голова ред. ради та автор передмови В. П. Черних. 3-тє вид., переробл. і доповн. - К.: «МОРІОН», 2016. - 1952 с.

8. Дыбская В. В., Зайцев Е. И., Сергеев В. И., Стерлигова А. Н. Логистика. Полный курс МВА / Под ред. В. И. Сергеева. - М.: Эксмо, 2013. - 944 с.

9. Пасічник А. М., Лебідь І. Г., Кутирєв В. В., Бугерко К. М. Проблеми та перспективи розвитку логістичного аутсорсингу в транспортній системі України // Управління проектами, системний аналіз і логістика. Ч. 1. Серія Технічні науки. - К.: НТУ, 2014. - Вип. 14.

10. Біловодська О. А., Латунова Д. А. Дослідження сутності логістичного аутсорсингу як чинника ефективного функціонування вітчизняних підприємств // Бізнесінформ. - 2014. - № 12. - С. 485-489.

11. Постанова Кабінету Міністрів України від 30 листопада 2016 р. № 929 «Про затвердження Ліцензійних умов провадження господарської діяльності 3 виробництва лікарських засобів, оптової та роздрібної торгівлі лікарськими засобами, імпорту лікарських засобів (крім активних фармацевтичних інгредієнтів)» [Електронний pecypc]. - Режим доступу: zakon2.rada.gov.ua/laws/show/929-2016-п

12. Електронний ресурс. - Режим доступу: region.diklz.gov.ua/control /ter/uk/ publish/article/860761;jsessionid=68C55BD1732B071544C40646EFBB8316

13. Шарчук T. В. Логістичний аутсорсинг - шлях до оптимізації управління бізнес-процесами підприємства // Вісн. Нац. ун-ту «Львівська політехніка» Серія Логістика. - 2008. - № 633 [Електронний ресурс]. - Режим доступу: http://www.nbuv. gov.ua/portal/natural/Vnulp/Logistyka/2008_633/122.pdf. 
14. Станіславик О. В., Коваленко О. М. Сучасні аспекти розвитку логістичного аутсорсингу в Україні // Інформаційні технології в освіті, науці та виробництві. 2012. - Вип. 1 (1). - Р. 107-114.

15. Посилкіна О. В., Хромих $A$. Г. Інноваційна парадигма розвитку логістичної діяльності суб' єктів фармацевтичного ринку / Управління інноваційним процесом в Україні: налагодження взаємодії між учасниками: Тези доп. V Міжнар. наук.-практ. конф., MIPU-2014, 22-23 травня 2014 р. [Електронний ресурс]. - Режим доступу: http://ena.lp.edu.ua:8080/handle/ntb/29371

16. Ван ден Берг Йерун Питер. Склад как конкурентное преимущество. Пер. с англ. - М.:АХЕLOT: Альпина Паблишер, 2015. - 337 с.

17. Партин Г. О., Дідух О. В. Основні види аутсорсингу та їх застосування в управлінні діяльністю підприємства / Сучасні проблеми економіки і менеджменту: Тези доп. міжнар. наук.-практ. конф. - Львів: В-во НУ «Львівська політехніка», 2011. - C. 637-638.

18. Анікін Б. А., Рудая І. Л. Аутсорсинг і аутстаффінг. Високі технології менеджменту. - М.: ІНФРА-М, 2009. - 320 с.

19. Тропіцина Ю. С. Теоретико-методичне забезпечення використання аутсорсингу на машинобудівному підприємстві: Дис. ... канд. економ. наук: спец. 08.00.04 «Економіка та управління підприємствами (за видами економічної діяльності)». Харків, 2016. - 366 с.

20. Колдовский В. ИТ-аутсорсинг в Украине: не благодаря, а вопреки[Электронный pecypc]. - Режим доступа: http://ko.com.ua/it-autsorsing_v_ukraine_ne_blagodarya_a_ vopreki_79367

Надійшла до редакції 20 липня 2017 року.

М. В. Белоус ${ }^{1}$, А. П. Шматенко ${ }^{1}$, А. А. Рыжов ${ }^{2}$, Т. С. Райкова ${ }^{2}$, Д. В. Дроздов ${ }^{1}$

${ }^{l}$ Украинская военно-медицинская академия, г. Киев

2 Запорожский государственный медицинский университет

ЛОГИСТИЧЕСКИЙ АУТСОРСИНГ В ФАРМАЦИИ: ТЕОРИЯ И ПРАКТИКА

Ключевые слова: фармацевтическая логистика, аутсорсинг

А Н Н О Т А Ц И Я

В настоящее время внедрение и применение логистического подхода к управлению ресурсами позволяет фармацевтическим предприятиям повысить их социальную, экологическую и экономическую эффективность.

Цель статьи заключается в исследовании сущности понятия, уровней и видов логистического аутсорсинга в практической фармации.

Для достижения цели исследования проведен анализ зарубежной и отечественной научной литературы, действующей нормативно-правовой базы Украины. Методами исследования были библиографический и аналитический.

Результаты исследования указывают на то, что в настоящее время аутсорсинг является одной из основных логистических стратегий отечественных фармацевтических предприятий, который активно используется в сфере IT-технологий и складских услуг. Вместе с тем для обеспечения качественного предоставления аутсорсинговых услуг необходима нормативно-правовая база, стандартизирующая взаимодействия между фирмой-заказчиком и аутсорсером, а также разработка стандартов предоставления услуг определённого вида аутсорсинга. Широкое внедрение логистического аутсорсинга как современной формы оптимизации логистических бизнес-процессов 
требует формирования профессиональной компетенции у будущих провизоров-специалистов по фармацевтической логистике, её инструментам и стратегиям, т. е. подготовки конкурентоспособных профессионалов, имеющих возможность работать в различных направлениях практической фармации.

Было бы целесообразно ввести тему «Логистический аутсорсинг в практической фармации» в учебный процесс подготовки студентов фармацевтических факультетов (ВУЗов), провизоров-интернов, магистрантов и слушателей факультетов последипломного образования. Это улучшит теоретическую и практическую подготовку будущих провизоров-специалистов и позволит им в дальнейшем применить полученные знания по логистическому аутсорсингу в деятельности фармацевтических предприятий.

\section{V. Bilous ${ }^{1}$, O. P.Shmatenko ${ }^{1}$, O. A. Ryzhov ${ }^{2}$, T. S. Raikova ${ }^{2}$, D. V. Drozdov ${ }^{1}$ ${ }^{1}$ Ukrainian Military Medical Academy \\ ${ }^{2}$ Zaporizhzhia State Medical University \\ LOGISTIC OUTSOURCING IN PHARMACY. THE THEORY AND PRACTICE}

Key words: pharmaceutical logistics, outsourcing

\section{A B S T R A C T}

Today, the introduction and application of a logistics approach to resource management allows pharmaceutical companies to increase their social, environmental and economic efficiency.

The article is aimed to research the essence of the concept, types and party of logistic outsourcing in practical pharmacy. To reach the aimreview of foreign and domestic scientific sources and the existing legal framework of Ukraine on this issue have been analyzed. Investigation methods were bibliographic and analytical ones.

The results of these studies indicate the today outsourcing is one of the main logistics strategies of domestic pharmaceutical companies, which is actively used in the sphere of ITtechnologies and warehouse services. At the same time for ensuring high-quality providing outsourcing services, a legal and regulatory framework is needed that standardizes the interaction between firm customer and the outsourcer, also the development of standards for the provision of services of a certain type of outsourcing. Wide introduction of logistics outsourcing, as a modern form of optimization of logistics business processes, requires the formation of professional competence among future pharmacists in pharmaceutical logistics, its tools and strategies, i.e. training of competitive professionals capable of working in various directions of practical pharmacy.

Introduction of the topic «Logistic outsourcing in practical pharmacy» in the educational process of students of pharmaceutical faculties (university), pharmacists-interns and pharmacists at the postgraduate level of training is necessary. It will improve the theoretical and practical training of future specialist pharmaceutists and will allow them to apply the knowledge which would be gained in the future in logistics outsourcing in the activities of pharmaceutical companies. 